\title{
When Kids Hurt Other Kids: Bullying in Philippine Schools
}

\author{
Margaret S. Sanapo \\ College of Policy Science, Ritsumeikan University, Ibaraki-Osaka, Japan \\ Email: maggie-s@fc.ritsumei.ac.jp
}

How to cite this paper: Sanapo, M. S. (2017). When Kids Hurt Other Kids: Bullying in Philippine Schools. Psychology, 8, 2469-2484.

https://doi.org/10.4236/psych.2017.814156

Received: November 9, 2017

Accepted: December 17, 2017

Published: December 20, 2017

Copyright $\odot 2017$ by author and Scientific Research Publishing Inc. This work is licensed under the Creative Commons Attribution International License (CC BY 4.0).

http://creativecommons.org/licenses/by/4.0/

\section{(c) (i) Open Access}

\begin{abstract}
This research looked into prevalence rate of bullying victimization and perpetration as well as teachers' response to bullying incidence in the Philippines. A total of 340 sixth graders from five different schools in Western Visayas participated in the study. Slightly more than half $(54.1 \%)$ of the sample were boys and $45.9 \%$ were girls. Descriptive statistics were used to analyze data gathered from the survey. Children's self-reports revealed that prevalence rate for victimization was $40.6 \%$ and that for perpetration was $23.8 \%$. Similar to previous literature, results also showed that there were significantly more boys than girls who reported to be victims $\left(\chi^{2}(1, \mathrm{~N}=340)=4.26, p=0.039\right)$ and bullies $\left(\chi^{2}(1, N=340)=4.35, p=0.037\right)$. Regardless of gender, verbal bullying came out as the most common type of bullying children experienced as a victim and bully. Teachers' response to bullying was all in line with direct sanctions, i.e. verbal reprimands, temporary removal from class, withdrawal of privileges, and suspension, which were imposed on individuals involved in bullying as bullies. Although all teachers and school personnel were required to report bullying cases they had knowledge of to the child protection committee in their institution, very few did so. These findings suggest the need for a more effective bullying prevention program and a careful examination of the implementing rules and guidelines of RA 10627, otherwise known as the Anti-Bullying Act of 2013.
\end{abstract}

\section{Keywords}

Filipino Children, School Bullying, Direct Sanctions, Anti-Bullying Act of 2013

\section{Introduction}

Although aggression is one of the elements of bullying, not all violence or ag- 
gressive actions in school can fall under this category. For bullying to occur, Olweus (1993) mentioned that a student must be repeatedly exposed to negative behavior of his/her peers. Moreover, the perpetrator must have a deliberate intention to harm the victim and the latter should have limited power to fight back (Nansel et al., 2001; Olweus, 1993). Without the power imbalance between the aggressor and the victim as well as regularity of the aggressive act, a negative action done by one child to another cannot be considered as bullying; rather, it will fall under violence or aggression (Olweus, 1993).

Bullying is categorized into four types, namely: physical, verbal, cyber, and relational. Physical bullying includes all forms of physical harm done on the victim such as kicking, shoving, punching, and the like. Verbal bullying is usually in the form of derogatory remarks or insults hurled at the target. This may include but not limited to name-calling, taunting, teasing in a hurtful way, and making fun of the individual (Berger, 2007; Wang, Iannotti, \& Nansel, 2009). Relational bullying involves social seclusion. It may be done in the form of spreading rumors and lies about the victim in order to make others avoid socializing with him/her (Wang et al., 2009). Cyberbullying, on the other hand, occurs electronically, and has proven to be more damaging because it often relates to victims' depressive state, delinquent behavior and substance abuse (Mitchell, Ybarra, \& Finkelhor, 2007) as well as suicidal thoughts and suicide attempts (Hinduja \& Patchin, 2010).

In Asia-Pacific, the most common type of school bullying was verbal, e.g., "being made fun of" or "being called names" (Chen, 2015; Lai, Ye, \& Chang, 2008). A similar study in South America also found verbal bullying as the most pervasive school bullying experience of youngsters (Silva, Pereira, Mendonca, Nunes, \& de Oliveira, 2013). However, in Egypt and Ghana, physical assaults were the most common form of bullying among students (Wilson, Dunlavy, \& Berchtold, 2013). The same was true for Singaporean children in one study (Kwan \& Skoric, 2012). Cyberbullying, though becoming controversial recently with a number of youth suicides, was said to be less prevalent than that of traditional or face-to-face bullying (Chen, 2015; Gofin \& Avitrzour, 2012; Lapidot-Lefler \& Dolev-Cohen, 2015; Modecki, Minchin, Harbaugh, Guerra, \& Runions, 2014).

As to involvement in school bullying, high rate of victimization of at least $40 \%$ was often reported by African countries (Kubwalo, Muula, Siziya, Pasupulati, \& Rudatsikira, 2013; Owusu, Hart, Oliver, \& Kang, 2011; Siziya, Rudatsikira, \& Muula, 2013). In the Philippines, two studies conducted by foreign researchers in 2008 showed different results. In one study, the prevalence rate was $35.5 \%$ (Rudatsikira, Mataya, Siziya, \& Muula, 2008) while in another it was 85.5\% (Lai et al., 2008). However, in a research conducted by Fleming and Jacobsen (2009) involving 19 low and middle income countries in which Philippines was included, prevalence rate in the country was only $37.1 \%$, or a lot closer to that found by Rudatsikira et al. (2008). As to cyberbullying, Australia showed to have a high number of incidence rate in the youngsters' lifetime at 27\% (Cross et al., 2012), Japan at 18\% (Aoyama, Utsumi, \& Hasegawa, 2012), the US at $17 \%$ 
(Bauman, 2012), and South Korea at 12\% (Tippett \& Kawk, 2012). Respondents for these studies ranged from grade 5 to 11 . It should be noted that these are just glimpses of the pervasiveness of bullying in the countries mentioned and may not be true for the whole nation.

Bullying research has also shown that victimization was found to be higher than perpetration. For example, in one study in Romania which used self-reports, it was found out that $40.5 \%$ of 264 students surveyed indicated that they were victims of school bullying and only $33.8 \%$ admitted that they had bullied others (Belden-Galea, Jurcau, \& Tigan, 2010). The same was true for sampled students in Turkey (Arslan, Hallett, Akkas, \& Akkas, 2012; Tayli, 2013).

With regard to gender differences in school bullying experience, several studies have shown that boys were more involved as perpetrators and victims than do girls (Berger, 2007; Caravita, Gini, \& Pozzoli, 2012; Cosma \& Baban, 2013; Jansen et al., 2012; Khamis, 2015; Siann, Callaghan, Glissov, Lockhart, \& Rawson, 2006; Silva et al., 2013; Tayli, 2013; Wang et al., 2009; Wu et al., 2015) and were more likely to be victims of direct form of bullying such as physical fights (Cheng et al., 2010; Jansen et al., 2012; Lai et al., 2008; Shujja et al., 2014; Silva et al., 2013; Uwusu et al., 2011) while girls were more likely to experience relational bullying (Cheng et al., 2010; Silva et al., 2013).

As to gender and frequency of victimization, results were mixed. On the one hand, research has shown that boys and girls did not differ significantly in the frequency of victimization (Malecki et al., 2015), but on the other hand, it revealed that boys have higher self-reported frequency of being bullied than do girls (Chen, 2015; Fleming \& Jacobsen, 2009; Nansel et al., 2001).

With regard to intervention programs that could help reduce the prevalence rate of bullying in schools, involving the community, family (Mann, Kristiansson, Sigfusdottir, \& Smith, 2015), especially parents (Jones \& Augustine, 2015; Lester et al., 2017), students (Cross et al., 2011; Jones \& Augustine, 2015) and teachers (Duy, 2013) reduced the odds of young people engaging in bullying behavior. In another study, arousing the bullies' empathy for their victims and condemning their actions proved to be effective in increasing their intention to stop their aggressive behavior (Garandeau, Vartio, Poskiparta, \& Salmivalli, 2016). However, Ken Rigby, a school bullying expert, had found in his study that the most commonly used intervention methods in schools were direct sanctions or "the imposition of disciplinary sanctions on the person or persons identified as responsible for the bullying" (Rigby, 2014: p. 409). These direct sanctions include verbal reprimands, temporary removal from class, and withdrawal of privileges, among others, which were imposed on individuals involved in bullying others (Rigby, 2014). He said that these may deter bullies to perpetuate the act but only temporarily. In addition, he also suggested that this kind of response is only reactive and it does little to prevent students from engaging in bullying behavior in the future.

In the Philippines, with the passing of Republic Act (RA) 10627, otherwise known as the Anti-bullying Law of 2013, schools are required to establish their 
own anti-bullying programs which includes the formation of a committee who would ensure the protection of children against abuses from their peers as well as adults, formulation of awareness programs to increase students' knowledge of bullying, and provision of counseling programs for both bullies and victims. Educators, school personnel, and students are also encouraged to report school bullying they have witnessed to proper channels.

This study was conducted to find out the prevalence rate of the different forms of school bullying among the sixth graders in selected schools in Western Visayas; feelings of victims and bullies after the act; proportion of males and females who engaged in school bullying as a victim and perpetrator, and; teachers' response to bullying cases they have witnessed. It is hoped that this research could be of help, especially to Filipino educators and policy makers in formulating effective bullying programs in schools.

\section{Method}

\subsection{Participants}

A total of 340 sixth graders from five different public schools in Western Visayas, which is located in central Philippines participated in the study. They were chosen using cluster sampling. Each cluster consisted of students in one grade six class. On the average there were six classes (or clusters) per school. In a school with only five grade six classes, two were chosen and those with six-seven, three classes. This sampling technique was used for ease of data gathering and to minimize disruption in the normal activities of the children.

The average age for participants during data gathering was 12.1 . Slightly more than half $(54.1 \%, \mathrm{n}=184)$ of the sample were boys and $45.9 \%(\mathrm{n}=156)$ were girls. The number of respondents per school and gender distribution were proportional to the total population of their sixth graders.

The total sample size was approximately $30 \%$ of the entire grade six populations in the selected five schools. In determining how many will be selected from each school, $30 \%$ of the total population of grade six pupils was first computed. Then, the total number of sixth graders per school was divided by the total grade six population of the five schools multiplied by 100 (to get the percentage). So if one school's total sixth graders was $28 \%$ of the entire grade six population in all five schools, they also contributed $28 \%$ to the total sample. This is to avoid overrepresenting one school while under representing another.

\subsection{Research Instrument}

The questionnaire used for this research was constructed by the author. This is to ensure that questions included are appropriate to the Philippine context. It consisted of an open-ended and multiple-choice items which were all expressed in the participants' mother tongue. Questions on gauging respondents' experience on bullying were based on Olweus' (1993) definition of the phenomenon. This includes questions such as: 1) Did you initiate a fight with other children in 
the last six months? If yes, how often in a week? 2) How do you fight with him/her? How often do you do this in a week? 3) Who do you always fight with? 4) Are your victims capable of fighting back with you?

The follow-up question for item \#1 was meant to find out whether participants initiate the fight on a regular basis. If they do, it would satisfy the first criterion for an act to be considered as bullying: regularity of the aggressive behavior. This question was also the basis for determining the frequency of fights or bullying. The second question was included to find out the type of aggressive acts or bullying they usually do with their peers. The third question was meant to find out who they usually victimize-are the victims younger, older, of the same age, male, or female, among others. The third and fourth questions were very important because they could determine whether there was a power imbalance between the bully and victim, a very important component of bullying.

Questions aimed at identifying the victim were also included. They were similar to the one aforementioned, but instead of asking questions like, "Did you initiate a fight with other children in the last six months?" it was rephrased as, "Did other children initiate a fight with you in the last six months?" In addition, instead of asking them, "Who do you always fight with?" it was posed as, "Who usually initiates a fight with you?" Other questions include: "Are the children who initiate a fight with you those you can easily fight back?"

The children were also asked motives or reasons for bullying other children, how they feel after engaging in bullying or fights as an initiator of the behavior or as a victim and what their teachers do after witnessing the event.

The said questionnaire was pretested among children of similar age and educational level in the same area a few months before the study was conducted. This pretest was done to find out whether the items were aptly phrased in the participants' mother tongue or not. The pretest showed that questions were well-understood by local children.

\subsection{Procedure}

This study was conducted during the first quarter of 2014. All public elementary schools located in each of the town proper of a selected semi-urban district in Western Visayas were included in the current research. The target participants were grade six pupils and they were recruited through their school heads. The survey was conducted during the children's recess so as not to disrupt their classes.

In lieu of a research ethics committee which was yet to be established in the district where the study was conducted, the principals or head of schools selected for the survey were the ones who reviewed the nature of the research. A letter, which detailed the purpose of the study, survey procedure, and students' participation was submitted to each of the school principals for review. A copy of the questionnaire in the respondents' dialect was also attached with the letter to enable principals concerned to get a clear understanding of what will be asked from their students. After a week's deliberation with their teachers in the sixth 
grade and representatives of the parent-teacher association, all of them granted permission to the author/researcher to conduct the survey in their institutions. Although the study was approved by school authorities concerned, participants' assent was still solicited. They were informed of the nature of the study, their participation in it, and how their responses will be used and analyzed. They were also told that although their schools agreed for them to participate, they still have the right to withdraw participation should they feel uncomfortable with the questions in the survey questionnaire. None of them withdrew.

\subsection{Data Analysis}

Cross tabulations were done to determine the number of male and female victims and perpetrators of school bullying while chi-square analysis was used to find out whether there was a significant difference between the number of boys and girls who reported to be bullies or victims. Frequencies and percentages were also used to describe the data.

\section{Results}

\subsection{Prevalence of Bullying}

Children's self-reports revealed that there were more of them who indicated they were victims of school bullying $(40.6 \%, \mathrm{n}=138)$ than those who admitted they were the perpetrators $(23.8 \%, \mathrm{n}=81)$. Of the 138 participants who were victimized, 84 (60.9\%) were males and 54 (39.1\%) were females. As to the bullies, the majority were also boys $(64.2 \%, \mathrm{n}=52)$. Chi-square analysis showed that indeed there were significantly more boys than girls who were victims $\left(\chi^{2}(1, \mathrm{~N}=340)=\right.$ $4.26, \mathrm{p}=0.039)$ and bullies $\left(\chi^{2}(1, \mathrm{~N}=340)=4.35, \mathrm{p}=0.037\right)$.

The majority of female victims $(74.1 \%, \mathrm{n}=40)$ experienced bullying from both sexes, while only $41.7 \%(n=35)$ for male victims. But when it comes to being bullied by the same sex, more than half of the boys $(56.0 \%, \mathrm{n}=47)$ and only $14.8 \%(\mathrm{n}=8)$ of the girls indicated that they had experienced such type of victimization.

When bullies were asked as to who they usually torment in school, $53.8 \%$ ( $\mathrm{n}=$ 28) of the boys reported that their victims came from both sexes. But there were $40.4 \%(n=21)$ of them who bullied only boys and $5.8 \%(n=3)$ only girls. For the female bullies, most of them $(65.5 \%, \mathrm{n}=19)$ indicated that their victims were either their fellow girls or boys. Only $17.2 \%(n=5)$ of them victimized just boys or just girls.

\subsection{Types of School Bullying Done by Bullies}

Prevalence rates for bullying types done by perpetrators are presented in Table 1. As shown in this table, all four types of school bullying, namely: verbal, physical, cyber, and relational were done by bullies in the current study. Verbal bullying topped the list at $60.5 \%(\mathrm{n}=49)$. This included threatening their victims, calling them names, saying hurtful words to them, and taunting them because of 
Table 1. Forms of bullying done by bullies.

\begin{tabular}{ccc}
\hline Forms of Bullying & Males (\%) & Females (\%) \\
\hline Verbal & 63.46 & 55.17 \\
Physical & 17.31 & 3.45 \\
Cyber & 5.77 & 6.90 \\
Relational & 0 & 3.45 \\
Verbal and physical & 9.61 & 10.34 \\
Verbal and cyber & 3.85 & 13.79 \\
Verbal and relational & 0 & 3.45 \\
Verbal, physical, and cyber & 0 & 3.45 \\
\hline
\end{tabular}

their names, looks, or smell. Even when respondents were categorized by gender, verbal bullying still emerged as the most prevalent form of bullying done by both male $(63.5 \%, \mathrm{n}=33)$ and female $(55.2 \%, \mathrm{n}=16)$ bullies (see Table 1$)$. Table 1 also shows that there were more boys than girls $(n=9$ vs. $n=1)$ who used physical bullying to torment their peers. Surprisingly, relational bullying $(1 \%, \mathrm{n}=3)$ came out as the least prevalent even by female bullies. Boys reported to have never done it at all.

\subsection{Types of School Bullying Experienced by Victims}

Table 2 shows the prevalence rate for victimization. As shown in the table, verbal bullying also came out as the most frequent type experienced by victims regardless of gender. The pattern of responses is comparable to that of the bullies' experience, with relational form being exclusively experienced by girls.

A chi-square test was not performed for this bullying and victimization data because there were many cells which contained a frequency count lower than five, a criterion which should be met to obtain a reliable result.

\subsection{Frequency of Bullying Behavior}

In this section, only the top three categories were discussed. The total frequencies for victimization was 138 , while for bullying 84 .

Slightly more than half $(55.8 \%, \mathrm{n}=77)$ of the victims indicated that they were bullied less than once a week. Even when boys' and girls' responses were segregated, this still emerged as the most common frequency of bullying experience. Only around $15.2 \%(n=21)$ were victimized every day, closely followed by twice a week at $14.5 \%(\mathrm{n}=20)$.

This pattern was also reflected in the bullying behavior of bullies. The majority of them $(58.0 \%, \mathrm{n}=47)$ also indicated that they torment their victims less than once a week, about $17.3 \%(n=14)$ bullied their peers twice a week, followed by every day at $14.8 \%(\mathrm{n}=12)$. This was true for both male and female bullies. 
Table 2. Forms of bullying experienced by victims.

\begin{tabular}{ccc}
\hline Forms of bullying & Males (\%) & Females (\%) \\
\hline Verbal & 61.90 & 61.11 \\
Physical & 21.43 & 7.41 \\
Cyber & 1.20 & 5.56 \\
Relational & 0 & 3.70 \\
Verbal and physical & 8.33 & 5.56 \\
Verbal and cyber & 4.76 & 16.66 \\
Verbal, physical, and cyber & 2.38 & 0 \\
\hline
\end{tabular}

\subsection{Why Bullies Bully Other Children}

Bullies reported several reasons why they bully other children (Figure 1). The most common of which was retaliation or getting even (44\%). Aside from retaliation, just for fun also got a double figure (33\%). Other reasons had something to do with the physical attribute of the victim (i.e. smells bad or ugly).

\subsection{Feeling of Bullies after Bullying Others}

Although retaliation came out as the most frequent reason for bullying other children, only a few number of participants (13\%) felt good for hurting their peers. As shown in Figure 2, "feeling sorry" came out as the most common reaction to bullying others. This was followed by "feeling guilty" (29\%) and "scared" (27\%). However, these did not stop them from repeating what they had been doing as shown in the prevalence rate of bullying in the selected areas.

\subsection{Feeling of Victims after Being Bullied}

When victims were asked to indicate what they felt after being bullied, the majority indicated negative reactions such as anger, sadness, felt like crying, and embarrassment with anger (30\%) as the topmost reaction (Figure 3). A few of them (8\%) reported that they didn't feel anything at all.

\subsection{Teachers/Class Advisers' Response to Bullying}

According to the majority (78\%) of the participants, the most common reaction of teachers to bullying incidence they have witnessed was stopping the act immediately and resolving the matter right there and then. This means teachers would ask students involved to say sorry to each other, reprimand or give sanctions to bullies, and make sure both bullies and victims become "friends". These reprimands were usually verbal in nature which included scolding the bullies or threatening to report them to their parents, guidance office, or the school's principal. Other sanctions were withdrawal of privileges, e.g. not allowing them to have a recess, temporary suspension from classes, or in worst case scenarios being kicked out of school. The latter sanction is only applied after all the alternatives have been exhausted and are proven to be ineffective to solve the problem. 


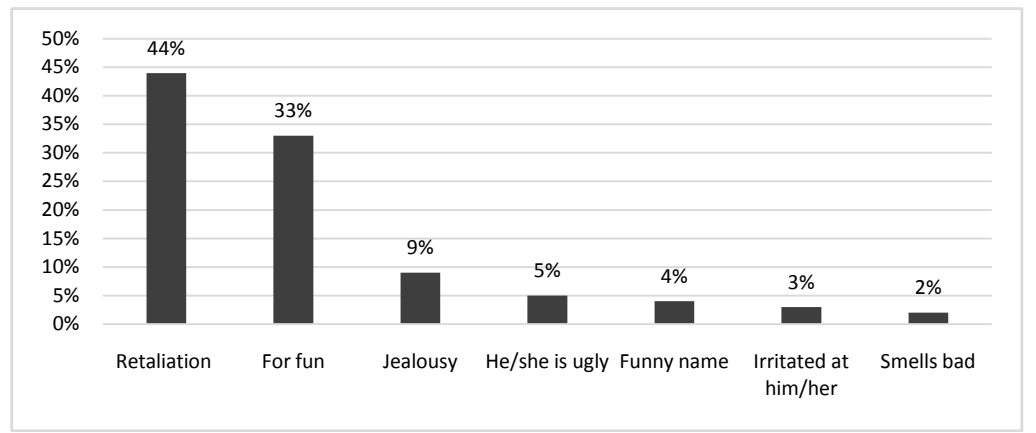

Figure 1. Why bullies bully other kids.

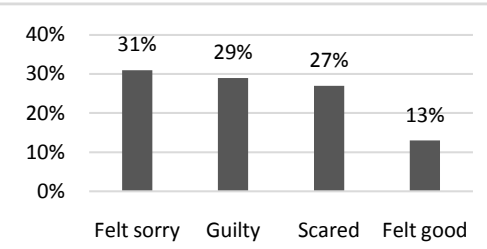

Figure 2. Feeling of bullies after bullying other children.

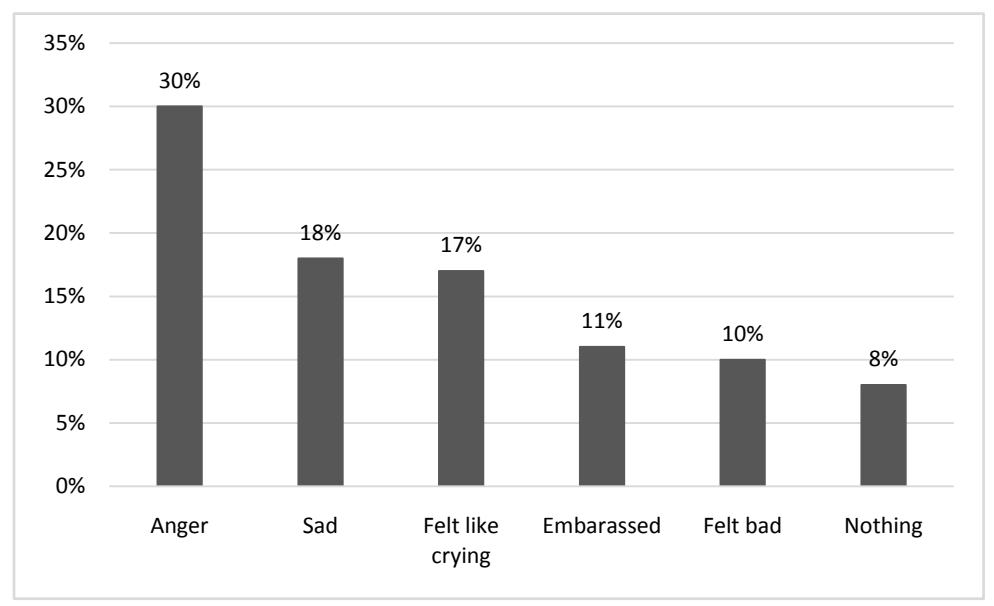

Figure 3. Feeling of victims after being bullied

Although teachers or school personnel are expected to report the bullying incidence they have witnessed personally to the committee of child protection to which the guidance counselor is a member, only few did so according to participants. In fact, there were only $9 \%$ of respondents who indicated this type of response to bullying from their teachers or class advisers. About the same number (10\%) said that their teachers informed parents of children involved in the bullying incident. The remaining three percent $(3 \%)$ of participants indicated that their educators have done nothing about the bullying case they have witnessed.

\section{Discussion}

The results have shown that $40.6 \%$ or roughly four out of 10 Filipino children experienced bullying from their peers. This prevalence rate is comparable to two 
studies done in the Philippines (Jacobsen \& Fleming, 2009; Rudatsikira et al., 2008) but a lot different from that reported by Lai et al. (2008). The discrepancy in prevalence rate of the four studies could be attributed to the time range by which bullying involvement was measured. For example, in Lai et al. (2008), participants were asked to report their lifetime experience in bullying, whereas in the other three including the current study, it was only within a year.

When compared to prevalence rate of victimization in studies in other countries, it was either a lot higher (Shujja et al., 2014; Wu, et al., 2015), lower (Siziya et al., 2012; Wang et al., 2009) or just at par (Kubwalo et al., 2013; Owusu et al., 2011).

When respondents' experiences were examined according to gender, it was revealed that there were significantly more Filipino boys who reported to be victims and bullies as compared to girls. This result is consistent with several studies (Berger, 2007; Caravita et al., 2012; Cosma \& Baban, 2013; Jansen et al., 2012; Khamis, 2015; Siann et al., 2006; Silva et al., 2013; Tayli, 2013; Wang et al., 2009; Wu et al., 2015). In addition, the study also supports previous literature that says boys were more victimized by their fellow boys than girls being victimized by girls (Shujja et al., 2014).

As to the most common form of bullying experienced by both perpetrators and victims, current results were similar to that found by Lai et al. (2008) and Silva et al. (2013) which showed verbal bullying as the most frequent form experienced by young respondents but differed from that found by Wilson et al. (2013) and Kwan and Skoric (2012). Though other countries such as Australia (Cross et al., 2012), Japan (Aoyama et al., 2012), the US (Bauman, 2012), and South Korea (Tippett \& Kawk, 2012) showed double figures in cyberbullying rate, respondents in this study identified such form of peer abuse as the least common they experienced as bullies and victims as shown by a barely seven per cent prevalence rate. This difference could be due to age of respondents and access to electronics and the Internet. Participants in the abovementioned studies were adolescents in affluent nations who may have their own electronic devices equipped with Wi-Fi connection, whereas participants in the current research were 12-year olds, most of whom had no cell phones or computers of their own. In addition, the result of this study showing cyberbullying prevalence rate to be a lot lesser than that of traditional bullying was also consistent with findings from existing literature (Gofin \& Avitzour, 2012; Lapidot-Lefler \& Dolev-Cohen, 2015; Modecki et al., 2014).

With regard to the frequency of bullying behavior, the result showing that boys and girls alike showed similar frequency of victimization supports previous African study (Malecki et al., 2015), but contradicts that done by Chen (2015) and Nansel et al. (2001). In addition, the current research was also consistent with that done in Romania (Belden-Galea et al., 2010) and Turkey (Arslan et al., 2012; Tayli, 2013) that argued the incidence of victimization was higher than that of perpetration. 
What's new about this study was the fact that not all bullies had the intention to harm their victims. Some bullies said they were just teasing their victims in a 'friendly way'; however, this got out of hand and their victims were emotionally hurt or humiliated in the process. This is especially true for those who were making fun of their classmates because of the latter's funny name, physical defect, or peculiar characteristics. Although in Olweus' (1993) definition this type of behavior cannot be considered as bullying, it was identified as such in this study because according to RA 10627 any act done by one student to another that causes emotional harm or infringes on the rights of another student at school is considered as school bullying. Teachers in five selected schools also use this definition together with that of Olweus' (1993) in determining whether their students engage in bullying behavior or not.

As expected, victims reacted negatively to being bullied with the majority reported feeling angry towards their bullies. This anger could have motivated some to get back at their aggressor when they got an opportunity because Figure 1 shows retaliation as the most common motivation of bullies, who used to be victims, in hurting their targets. Although the majority reacted negatively to being bullied, a few others reported to have felt nothing about their experience. This may have something to do with how severe they perceived their experience was. It may be that those who felt nothing were those who had a mild form of victimization. For future research, looking into the relationship between victims' perception of their bullying experience and how they feel after being bullied could provide valuable insights on how to help them effectively.

As to teachers' response to bullying, it showed that they were more in line with direct sanctions (Rigby, 2014). Based on participants' reports, the focus of the intervention was the bullies as they were the ones who were reprimanded and threatened to be reported to their parents, guidance counselor, and principal. The victim seemed to be left out. It also implied that teachers' reactions were more in line with short-term intervention strategies which Rigby (2014) thought to have no significant impact on future behavior. Although RA 10627 required these educators to bring the bully and victim to the guidance counselor or the child protection committee for proper handling of the case, very few of them did more than stopping the act and reprimanding students involved. This seemingly inadequate response of educators with regard to school bullying incidence they had witnessed may be attributed to their schools' lack of established school bullying programs or lack of proper training in responding to such problem. Inasmuch as the study was conducted a few months after the implementation of the Anti-Bullying Act of 2013, it was somehow understandable that many schools have not yet established their own comprehensive anti-bullying intervention strategies during the data gathering period.

Research on intervention strategies (Cross et al., 2011; Duy, 2013; Garandeau et al., 2016; Jones \& Augustine, 2015; Lester et al., 2017; Man et al., 2015) recommended a number of ways on how to help minimize the bullying incidence in schools. These include involving the family especially the parents, 
community, students, teachers, and non-teaching school personnel in the preventative programs. Based on participants' reports in the current study, these strategies seemed to be not exhausted yet.

\section{Conclusion}

The results showed that school bullying was prevalent among children in selected schools in the Philippines. There was also evidence that there were more boys than girls who had experienced bullying both as a perpetrator and victim. However, when it comes to the frequency of victimization they did not show any significant difference between male and female participants. The study also revealed that verbal bullying and victimization was the common form experienced by the children. Their report also indicated that teachers' responses to bullying were mainly short-term intervention. Very few of them go beyond direct sanctions.

\section{Limitations}

The data relied primarily on participants' self-reports. As is often the problem with self-reports, there is always a tendency for respondents to withhold information or to respond in a biased way. Even when they try to respond as honestly as possible, there may still be instances when some of them would overestimate the occurrence of bullying when they see themselves as victims and underestimate those incidences when they are the bullies. However, given the limited time and resources, surveys employing self-reports was the most appropriate method for this study. In addition, school authorities in the area allowed only this type of data gathering method to be used with their students. Overt observation in the schools' premises was not authorized because the school heads felt it would disrupt the normal activities of their students.

\section{Recommendations}

Given the result of the current study, it is imperative for each school to train their teaching and non-teaching staff to properly identify students involved in bullying as well as teach them how to respond to such problem. Merely stopping the act when it occurs or using direct sanctions on children concerned may not be effective in the long run. Educators also need to address the root cause of bullying by talking with the bullies and victims alike or reporting them to their counselors for proper guidance. Schools also need to design programs which could help both bullies and victims and not just focus on one of them.

With regard to other stakeholders on the issue such as parents and community, schools could greatly benefit if these people are also actively participating in the formulation of preventative programs for school bullying. At present, parents' role or responsibilities in the prevention of peer abuse were not clearly stated in the Child Protection Policy and in the Implementing Rules and Regulations (IRR) of RA 10627. Although the Anti-bullying Law and the Child Protection 
Policy were clear about punishments for bullies, there was no corresponding clear-cut accountability for their parents or guardians. Unless parents or guardians are made answerable to the actions of their children, they will not actively participate in school bullying programs, especially if the victims are not their children. It may also be beneficial to all educational institutions in the country to solicit help from the community such as village leaders and elders, parish priests, or catechism teachers. Since Philippines is a catholic country, children look up to religious leaders and elders.

Last but not least, students should also be involved in all these to make them fully aware of their rights as well as that of their peers. By increasing their awareness and actively involving them in the formulation of anti-bullying programs, they may also learn how to protect themselves from abuses of fellow children. In addition, asking the help of popular students especially in influencing bullies to stop their aggressive behavior may also be effective inasmuch as young people listen to their influential peers.

\section{Declaration of Conflicting Interests}

The author declared that there is no potential conflict of interests as to the authorship and publication of this research article.

\section{Acknowledgements}

The author would like to thank all the principals of the schools and class advisers of students who participated in the study for their time and cooperation during data gathering.

\section{References}

Aoyama, I., Utsumi, S., \& Hasegawa, M. (2012). Cyberbullying in Japan. In Q. Li, D. Cross, \& P. K. Smith (Eds.), Cyberbullying in the Global Playground: Research from International Perspective (pp. 183-201). New York: Wiley-Blackwell.

Arslan, S., Hallett, V., Akkas, E., \& Akkas, O. A. (2012). Bullying and Victimization among Turkish Children and Adolescents: Examining Prevalence and Associated Health Symptoms. European Journal of Pediatrics, 171, 1549-1557. https://doi.org/10.1007/s00431-012-1782-9

Bauman, S. (2012). Cyberbullying in the United States. In Q. Li, D. Cross, \& P. K. Smith (Eds.), Cyberbullying in the Global Playground: Research from International Perspective (pp. 143-179). New York: Wiley-Blackwell. https://doi.org/10.1002/9781119954484.ch8

Belden-Galea, I. E., Jurcau, N., \& Tigan, S. I. (2010). Frequency of Bullying Behaviors in Secondary Schools in Cluj-Napoca. Applied Medical Informatics, 27, 62-66.

Berger, K. S. (2007). Update on Bullying at School: Science Forgotten? Developmental Review, 27, 90-126. https://doi.org/10.1016/j.dr.2006.08.002

Caravita, S. C. S., Gini, G., \& Pozzoli, T. (2012). Main and Moderated Effects of Moral Cognition and Status on Bullying and Defending. Aggressive Behavior, 38, 456-468. https://doi.org/10.1002/ab.21447

Chen, L. M. (2015). Self-Reported Frequency and Perceived Severity of Being Bullied 
among Elementary School Students. Journal of School Health, 85, 587-594.

https://doi.org/10.1111/josh.12289

Cheng, Y., Newman, I. M., Qu, M., Mbulo, L., Chai, Y., Chen, Y., \& Shell, D. F. (2010). Being Bullied and Psychological Adjustment among Middle School Students in China. Journal of School Health, 80, 193-199. https://doi.org/10.1111/j.1746-1561.2009.00486.x

Cosma, A., \& Baban, A. (2013). The Associations between Bullying Behaviors and Health Outcomes among Romanian School Children. Cognition, Brain, Behavior, 17, 263-276.

Cross, D., Monks, H., Hall, M., Shaw, T., Pintabona, Y., Erceg, E., \& Lester, L. (2011). Three-year Results of the Friendly Schools Whole-of-School Intervention on Children's Bullying Behavior. British Educational Research Journal, 37, 105-129. https://doi.org/10.1080/01411920903420024

Cross, D., Shaw, T., Epstein, M., Monks, F., Dooley, J., \& Hearn, L. (2012). Cyberbullying in Australia: Is School Context Related to School Bullying Behavior? In Q. Li, D. Cross, \& P. K. Smith (Eds.), Cyberbullying in the Global Playground: Research from International Perspective (pp. 75-98). New York: Wiley-Blackwell. https://doi.org/10.1002/9781119954484.ch5

Duy, B. (2013). Teachers' Attitudes toward Different Types of Bullying Victimization. Psychology in the Schools, 50, 987-1002. https://doi.org/10.1002/pits.21729

Fleming, L. C., \& Jacobsen, K. H. (2009). Bullying among Middle-School Students in Low and Middle Income Countries. Health Promotion International, 25, 73-74. https://doi.org/10.1093/heapro/dap046

Garandeau, C. F., Vartio, A., Poskiparta, E., \& Salmivalli, C. (2016). School Bullies' Intention to Change Behavior following Teacher Interventions: Effects of Empathy Arousal, Condemning of Bullying, and Blaming of the Perpetrator. Prevention Science, 17, 1034-1043. https://doi.org/10.1007/s11121-016-0712-x

Gofin, R., \& Avitzour, M. (2012). Traditional versus Internet Bullying in Junior High School Students. Maternal and Child Health Journal, 16, 1625-1635. https://doi.org/10.1007/s10995-012-0989-8

Hinduja, S., \& Patchin, J. W. (2010). Bullying, Cyberbullying, and Suicide. Archives of Suicide Research, 14, 206-221. https://doi.org/10.1080/13811118.2010.494133

Jansen, P. W., Verlinden, M., Berkel, A. D., Mieloo, C., van der Ende, J., Veenstra, R. et al. (2012). Prevalence of Bullying and Victimization among Children in Early Elementary School: Do Family and School Neighborhood, Socioeconomic Status Matter? BioMed Central Public Health, 12, 494. https://doi.org/10.1186/1471-2458-12-494

Jones, J. R., \& Augustine, S. M. (2015). Creating an Anti-Bullying Culture in Secondary Schools: Characteristics to Consider When Constructing Appropriate Anti-Bullying Programs. American Secondary Education, 43, 73-84.

Khamis, V. (2015). Bullying among School-Age Children in the Greater Beirut Area: Risk and Protective Factors. Child Abuse \& Neglect, 39, 137-146. https://doi.org/10.1016/j.chiabu.2014.08.005

Kubwalo, H. W., Muula, A. S., Siziya, S., Pasupulati, S., \& Rudatsikira, E. (2013). Prevalence and Correlates of Being Bullied among In-School Adolescents in Malawi: Results from the 2009 Global School-Based Health Survey. Malawi Medical Journal, 25, 12-14.

Kwan, G. C. E., \& Skoric, M. M. (2012). Facebook Bullying: An Extension of Battles in School. Computers in Human Behavior, 29, 16-25. https://doi.org/10.1016/j.chb.2012.07.014

Lai, S., Ye, R., \& Chang, K. (2008). Bullying in Middle Schools: An Asian-Pacific Regional 
Study. Asia Pacific Education Review, 9, 503-515. https://doi.org/10.1007/BF03025666

Lapidot-Lefler, N., \& Dolev-Cohen, M. (2015). Comparing Cyberbullying and School Bullying among School Students: Prevalence, Gender, and Grade Level Differences. Social Psychology of Education, 18, 1-16. https://doi.org/10.1007/s11218-014-9280-8

Lester, L., Pearce, N., Waters, S., Barnes, A., Beatty, S., \& Cross, D. (2017). Family Involvement in a Whole-School Intervention: Mothers' and Fathers' Communication and Influence with Children. Journal of Child and Family Studies, 26, 2716-2727. https://doi.org/10.1007/s10826-017-0793-6

Malecki, C. K., Demaray, M. C., Coyle, S., Geosling, R., Rueger, S. Y., \& Becker, L. D. (2015). Frequency, Power Differential, and Intentionality and the Relationship to Anxiety, Depression, and Self-Esteem for Victims of Bullying. Child \& Youth Care Forum, 44, 115-131. https://doi.org/10.1007/s10566-014-9273-y

Mann, M. J., Kristiansson, A. L., Sigfusdottir, I. D., \& Smith, M. L. (2015). The Role of Community, Family, Peer, and Social Factors in Group Bullying: Implications for School-Based Intervention. Journal of School Health, 85, 477-486. https://doi.org/10.1111/josh.12270

Mitchell, K. J., Ybarra, M., \& Finkelhor, D. (2007). The Relative Importance of Online Victimization in Understanding Depression, Delinquency, and Substance Abuse. Child Maltreatment, 12, 314-324. https://doi.org/10.1177/1077559507305996

Modecki, K. L., Minchin, J., Harbaugh, A. G., Guerra, N. G., \& Runions, K. C. (2014). Bullying Prevalence across Contexts: A Meta-Analysis Measuring Cyber and Traditional Bullying. Journal of Adolescent Health, 55, 602-611. https://doi.org/10.1016/j.jadohealth.2014.06.007

Nansel, T. R., Overpeck, M., Pilla, R. S., Ruan, W. J., Simons-Morton, B., \& Scheidt, P. (2001). Bullying Behaviors among US Youth: Prevalence and Association with Psychosocial Adjustment. Journal of the American Medical Association, 285, 2094-2100. https://doi.org/10.1001/jama.285.16.2094

Olweus, D. (1993). Understanding Children's World: Bullying at School. Malden, MA: Blackwell Publishing.

Owusu, A., Hart, P., Oliver, B., \& Kang, M. (2011). The Association between Bullying and Psychological Health among Senior High School Students in Ghana, West Africa. Journal of School Health, 81, 231-238. https://doi.org/10.1111/j.1746-1561.2011.00590.x

Rigby, K. (2014). How Teachers Address Cases of Bullying in Schools: A Comparison of Five Reactive Approaches. Educational Psychology in Practice, 30, 409-419. https://doi.org/10.1080/02667363.2014.949629

Rudatsikira, E., Mataya, R. H., Siziya, S., \& Muula, A. S. (2008). Association between Bullying Victimization and Physical Fighting among Filipino Adolescents: Results from the Global School-Based Survey. Indian Journal of Pediatrics, 75, 1243-1247. https://doi.org/10.1007/s12098-008-0244-X

Shujja, S., Atta, M., \& Shujjat, J. M. (2014). Prevalence of Bullying and Victimization among Sixth Graders with Reference to Gender, Socio-Economic Status, and Type of Schools. Journal of Social Science, 38, 159-165.

https://doi.org/10.1080/09718923.2014.11893246

Siann, G., Callaghan, M., Glissov, P., Lockhart, R., \& Rawson, L. (2006). Who Gets Bullied? The Effect of School, Gender, and Ethnic Group. Journal of Educational Research, 36, 123-134. https://doi.org/10.1080/0013188940360202

Silva, M. A. I., Pereira, B., Mendonca, D., Nunes, B., \& de Oliveira, W. A. (2013). The In- 
volvement of Girls and Boys with Bullying: An Analysis of Gender Differences. International Journal of Environmental Research and Public Health, 10, 6820-6831. https://doi.org/10.3390/ijerph10126820

Siziya, S., Rudatsikira, E., \& Muula, A. S. (2012). Victimization from Bullying among School-Attending Adolescents in Grades 7 to 10 in Zambia. Journal of Injury and Violence Research, 4, 30-35. https://doi.org/10.5249/jivr.v4i1.84

Tayli, A. (2013). School Size as a Predictor of Bullying. International Journal of Academic Research, 24, 124-130. https://doi.org/10.7813/2075-4124.2013/5-5/B.19

Tippett, N., \& Kawk, K. (2012). Cyberbullying in South Korea. In Q. Li, D. Cross, \& P. K. Smith (Eds.), Cyberbullying in the Global Playground: Research from International Perspective (pp. 202-219). New York, NY: Wiley-Blackwell.

Wang, J., Jannotti, R. J., \& Nansel, T. R. (2009). School Bullying among Adolescents in the United States: Physical, Verbal, Relational, and Cyber. Journal of Adolescent Health, 45, 368-375. https://doi.org/10.1016/j.jadohealth.2009.03.021

Wilson, M. L., Dunlavy, A. C., \& Berchtold, A. (2013). Determinants for Bullying Victim ization among 11-16-Year Olds in 15-Low-and-Middle Income Countries: A Multi-Level Study. Social Sciences, 2, 208-220. https://doi.org/10.3390/socsci2040208

Wu, J., He, Y., Lu, C., Deng, X., Gao, X., Guo, L. et al. (2015). Bullying Behaviors among Chinese School-Aged Youth: A Prevalence and Correlates Study in Guangdong Province. Psychiatry Research, 225, 716-722. https://doi.org/10.1016/j.psychres.2014.11.004 